\title{
BLESSINGS IN THE QUR'AN BACK TO BASIC VIRTUE IN LIFE
}

\author{
Sri Mulyati \\ Syarif Hidayatullah State Islamic University (UIN) Jakarta \\ mulyati2003@yahoo.com
}

\begin{abstract}
This article explores the conception of blessing or baraka through Qur'anic perspective; tafsir. Blessing etymologically means al-ziyadah, value-added; al-Sa'adah; happiness, al$d u^{\prime} a$; a prayer, al-manfa'ah; expediency, al-Baqa'; eternal, al-taqdis; a sacred entity. This article utilizes a normative description method whereas many researches have been previously performed in a more rigorous manner. The primary source is Quranic verses in addition to prophet's narration, hadith as the secondary resource. It is found that there are various types of blessing exist in Quran, for example blesing related to Objects, person, and place. There are 14 verses in the Qur'an which have links with baraka concept. To conclude, the idea of blessing from the divine comes from the direction that is often neither expected nor materially limited, nor even measured, then all the additional value that cannot be measured by human senses.
\end{abstract}

Keywords: Baraka, Tafseer, al-Ziyadah, al-Manfa'ah.

\section{Introduction}

Blessing belongs to the issue in modern times relatively reluctant to be discussed. This is not because of people do not believe of its existent, rather they do not tend to feel its impact any longer for people are mostly respond it in an unmeasurable way. This writing is trying to trace the verses related to the term of baraka and hoping that Muslims still trust such concept exist and have implication in the real life.

To understand blessings is significant in the context of modern life that has the tendency to love the worldly matters. This can be characterized by the decline of moral and ethics of human life with various problems that wrapped around the Indonesian nation, such as the example of corruption that is rampant in all areas of public life. The economic system that supports the modern way of life and the fulfillment of needs encourages people to achieve the standardization of lifestyle as a value of life.

The concept of baraka is a strong concept that is present in practice of Muslims muamalah. Assessment of the blessings in the life of Muslims in Indonesia can be seen from various research results such as examples from the perspective of livelihood economics (Pasmadi, 2009 and Mulawarman, 2009), kultur (Afifah, 2015), sacred places (Fatah, 2017), norms and ethics in consumption (Siswandi, 2011), antropologi (Irawan, 2008), and others.

This paper is not intended for the inauguration of fatalist in the life of a Muslim because Islam teaches Muslims to continuously grow, advance and prosper in life. In addition, Islam also does not forbid Muslims to become wealthy. Islam brings clues to personal and communal happiness and their welfare in the world and the hereafter (Shihab, 2007). The essential part in the muamalah of Muslims case is the balance of value in life in this world. In terms of achievement of growth needs must be balanced with the traditions or values such as examples of baraka concept. This writing is an affirmation of the importance of one of the values in the life of Muslims. Therefore, the purpose of this writing is to explain the blessings in the Qur'an. 


\section{Methods}

Library research (literature research) is utilised in this article by utilizing the source of the literature to obtain information and searching the verses related to the word baraka, then using the interpretive approach of tafsir. This paper is a qualitative approach, where inward and interpretative perspective embraced (Moeloeng, 2002). A qualitative inquiry is based on a question of the problem from the author on the subject being observed. The inward perspective is a rule in finding the particular conclusions originally derived from the general discussion. While interpretative is performed by the author in interpreting the intent of a sentence, paragraph or statement. The research method applies a theme tafsir method (maudlu'i), a method of interpretation to understand the Qur'anic verses by focusing on the prescribed theme by studying carefully about the verses related and explaining important points through various Qur'anic exegesis. This is to form a decent understanding idea about the Qur'an's commentary on the theme discussed.

Primary sources in this study are al-Qur'an by Ministry of Religious Affairs of Indonesia and primary sources of tafsir such as Tafsir Ibn Kathir, Tafsir Fi Zhilal al-Quran and Tafsir al-Mishbah and some of Kutub al-Sittah. The next part of this article is a discussion of the notion of baraka concept, followed by concluding remarks.

\section{Discussion}

The word barakah etymologically means al-ziyadah, value-added; al-Sa'adah happiness, al-du'a that is prayer, al-manfa'ah expediency, al-Baqa' eternal, al-taqdis something sacred. As is the term that is tsubut god fi al-Khayr al-shay' (Al-Isfahani 1997) i.e. God set some kind of kindness in something (predetermined Allah). Thus the provisions of goodness that (al-Khayr / al-Sa'adah / al-ziyadah has a single meaning which belongs to God in every places. At first someone does not have anything then God put His blessings then that person becomes nobel. If the treasures are blessed then the property is good, the benefits and sufficient, even the value of the quality of its significance exceeds the value of the quantity. "Blessing of the divine comes from the direction that is often neither expected nor materially limited, nor even measured, then all the additional value that cannot be measured by human senses namely the blessings, baraka" (Shihab, 2007).

Isim fa'il of baraka is mubarik, because God is the only Giver of blessings then He specifically characterizes Himself with the atribute of tabarak (the Giver of abundant blessings). The word tabaraka is repeated nine times in the Qur'an (Shihab, 2007, p. 279). These verses are solely directed to God alone, never and improperly given to what and whoever, therefore He by Himself subhanahu al-mutabarik the Most Glory and the Most Giver of blessings.

Baraka also means to mention divine goodness in everything. There are about 14 verses in the Qur'an which have links with al-baraka (al-Firuzabadi, n.d.) : Baraka relates to places, i.e. Mecca as the house of worship as written in the Qur'an, Ali 'Imran 3: 96; see also al-Qasas 28: 30, and Masjid al-Aqsa (al Isra 17: 1). The location where the dialogue of Prophet Moses with Allah occured, also for the Prophet Ibrahim and Ishaq, blessings were given to both of them (al-Saffat 37: 113), also to the Prophet Noah (Hud 11: 48 ), as well as to the olive tree (al-Nur 24: 35). There is also blessing given to the night time, when the Quran was first revealed (al-Dukhan 44: 3 and al-Qadr). Qur'an as the Holy book also possesses the blessings (al-Anbiya '21: 50, al-An'am 6: 92 and 155), and (Sad 38: 29). God's blessing is also given to the people of the land who are faithful and devoted, and Allah will bestow blessings from heaven and earth (al-Araf 7: 96), even individual person will receive blessings from Allah (Maryam 19: 31). As for the land of Syria is included to be the blessed land for many Prophets were originated and born (al-Anbiya '21: 71, 81, al-Araf 7: 137, and Saba' 34: 18). 
In the Qur'an, Allah almighty is stated as the source of blessings and virtue, all kinds of goodness and blessings that exist in the creature is originated from Him. He who Wills to give blessings and kindness to whoever and whatever He choses, or remove and revoke the blessings. He can provide kingdom or take it away, He can glorify the one whom $\mathrm{He}$ wills, so He can humiliate who He wills, in His hands all virtues, and He is Almighty over all things (Ali 'Imran 3:26).

In addition, Qur'an claims that Allah as the source of all that is holy, the entire holy things refer only to the will of God, the Holy God (al-Quddus), a term which implies that the power of continously giving benefits is emanating from Him. In connection with al-Quddus, blessing is an influence that precedes all that God adheres attentively, for example the Quran, the Prophet, the five pillars of Islam, mosques and waliyullah. However, because Islam does not recognize priesthood, blessing does not use human beings as intermediary; all blessings come from God. (Ries, 1987).

Concerning the phenomenon of blessings, it can be explained that human beings as religious beings believe that there is an absolute Reality which is holy, transendence in the world by manifesting in this world and purifying them as well as making them into fact (Eliade, 1959). It is also explained that blessings as a tool for permanent contact with the Reality of this nature in order to accept the influence of His Mercy. Through blessings, the sanctity comes into existense, as one of the actions which is mysterious by which transcendent power becomes immanent in this world. In every blessing, a power intervenes to flow the benefits that originally from God who bestows to the creatures (Eliade, 1959).

\section{Forms of Blessings}

In Islam, it is believed that human beings will gain blessings through many ways, multi blessings will be obtained if man follow the guidance set forth by Allah in al-Qur'an and explanation given by the Messenger of God.

\section{Objects}

The verse describing the blessings of water, for example in the surah Qaf verse 9. Ibn Katsir describes the word mubarakan means benefits, Allah sends down blessed water from the sky, gives benefits to grow the gardens and grain harvested (al-Damasyqi, 1981, 372). Meanwhile Sayyid Qutb in his commentary explaining that the water that falls from the sky as a sign to enlighten the dead of people's heart before to fertile the dead earth, its fact shows the existence of special trace in our hearts, no doubt about it. The water here attributed with blessings and Allah makes it as a cause to grow the garden of the fruits and beans harvests (Qutb, fi Zhilal al-Quran, section 6).

According to Ibn Katsir the phrase baraka min al-sama' in Qaf verse 9, blessings from the sky means the raining water that drops from the sky, and baraka min al-ard means the various types of plants that grow on earth, (Ibnu Katsir, Tafsir al-Qur'an al-'Azhim, p. 234). Baghawi added that rainy water is called ma'an mubaraka because the benefits of it are always there, whereever the rain falls, it used to grow the plants and it is beneficial for human beings and animals to drink. This is reinforced by another verse which explains the importance of water for human life in Surat al-Anbiya '21:30. "And out of the water We made all things alive. So why do not they believe? Likewise in al-Nahl 16:10, al-Furqan 25: 48-50, and Qaf 50:11. And God called the rain with thahur (sacred) and rahmah (mercy) in accordance with the verses above, and the name of his word Rizq in al-Jatsiyah 45: 5). How great the rainwater benefits for all beings on earth, therefore, the rainwater containing extra ordinary blessings.

While Tafsir al-Tabari explains that God sends down water that is blessed (mataran mubarakan), which God grows the trees and seeds of plants. In addition that God grows with water, then plants would be sustenance for the servants (rizqan li al-ibad). Also with the 
descent of the waters from the sky Allah revives the dead land without plants. That is like God takes man out of the grave, lives on the Day of Judgement, after being in it with what Allah sends down water upon it. Furthermore, Tafsir al-Qurtubi explained that Allah sends down water from the clouds which many of His blessings (Kathir al-Barkah), i.e. the seed grows then harvest.

This verse shows the continuation of the exposition of the evidence of the power of Allah Almighty. According to Quraish Shihab, describes some of the impacts derived from the creation of the heavens and the earth. The first impact mentioned is what is produced jointly by the sky and the earth which is rainy water that produced from the sea and the river that lies on earth, then the water evaporates into the sky due to the heat that emanated from the sun in the sky. Here God mentions His gifts to His creatures by descending the water as the source of their lives on this earth (Shihab, 2007, p. 284).

Blessings of Zaitun tree, as described in al-Nur 24:35. The meaning of the hole that is not transparent (Mishkat) is a hole on the walls of the house that is not transparent to its next side, usually used for the place of lamps, or other goods. The meaning of the Zaitun tree that grows neither in the east (something), nor in its west is that the tree of Zaitun grows on the hilltop of the land, it may receive the sunlight both at sunrise and at the time of the sunset, so that the tree is fertile and the fruit produces good oil.

According to Imam Qurthubi, to mention of the Olive tree in particular because of its great benefits both in the country of Syria and in the land of Hijaz and wherever it is, in addition to the blessing of its benefits, the Olive tree can live without much maintenance i.e without having to water it or treated the soil as generally other plants (Qurthubi, Jami 'li Ahkam al-Qur'an, p. 114). Another blessing of the olive tree is the fruit could be eaten and its oil is the oil manifold clearer than other oils so beneficial for health of skin and other diseases, in addition, it can be used as a lamp of the brightest and clearest, and the oil can easily come out by itself without having to be blackmailed (Al-Baghawi, 1996, p. 246, Ibn al-Jawzi, Zad al-Masir vol. 6, p. 43).

Al-Qur'an referred to as the blessings that Allah has labelled as mubarak were repeated four times, namely al-An'am 6: 92, and 155, al -Anbiya '21: 50, and Shad 38: 29 with various names, namely: Al-Kitab al-Furqan, al-Dhikr al-Tanzil, Nur, Huda, Shifa, Rahmah, Mau'izhah, Mubarak, Mubin, Busyro, 'Aziz, Majid, Bashir, and nadzir (alQaththan, 1995, p. 21-23). The meaning of kitabun mubarak is a book that a lot of kindness and have eternal blessings, because it always gives glad tidings i.e multiple reward and huge forgiveness, as well as giving a threat to those who commit sins and immorality (Al-Razi, p. 30). Ibn al-Qayyim states that "The Quran is more worthy to be called by Mubarak than the others, because of the abundance of various kinds of goodness and the benefits and blessings therein (Al-Jawzi, p. 178) while Al-Alusi interprets the word blessed with abundant benefits, since it includes the benefits of this world and Hereafter and include knowledge of the current and prior (Ruh al-Ma'ani fi Tafsir al-Qur'an al-'Azhimwa Sab' al-Mathani (Beirut: Dar Ihya'al-Turath al-'Arabi, n.d., p. 221). Al-Shanqiti explained that mubarak means that many blessings and goodness in abundance, because in it there are a lot of good for the world and in the Hereafter (al-Shanqiti, 2003, p. 587).

\section{People and Places}

The blessing also given by God to the local residents who believe and devoted, and Allah will bestow the blessings from the heavens and the earth (al-A'raf 7: 96). The word lau in the above verse, if it used in the sense of modality towards something, becomes impossible to happen. This contrasts with the word idha, when it is used to describe the presupposition for something that is alleged to occur. The use of the word lau here shows that the abundance of blessing for the residents of the rebellious countries is impossible. Examples in the history of Islam is the people of Mecca who disobeyed God, experienced 
difficult times even famine for seven years, while Medina was peaceful and prosperous under the guidance of the Messenger of Allah.

Faith makes one always feel secure and optimistic and this leads him to live calmly and can concentrate and full of confidence that Allah is All-Giving sustenance and guaranteeing it (Surah Hud 11: 6 and QS Al-Ankabut 29: 60). The piety of the people of one country makes them work together in virtue and help to manage the earth and enjoy it together. The more power and strength of cooperation they produce, the more benefit can be achieved. Allah will give blessings to those who believe and piety and take it away from the unbelievers and rebels.

The word fatahna taken from the word fataha means open, essentially means eliminating barriers that prevent something to enter. If God intervenes to get rid of the barrier, it means that the door will open very widely and this leads to the overflow of all kinds of virtue through that door. Another verse that speaks of divine blessing gives the impression that the blessing is the outpouring of various sources, from heaven and from the earth through all its pointers. The blessing of the heavens can also be understood in the sense of spiritual blessing while earthly blessings means a material blessing (Shihab, 2007, p 182185).

Mecca as a blessed place enshrined in Al 'Imran 3: 96. Allah says that the first house built for the human to worship is the Baitullah which is in Bakka (Mecca) blessed and guided for all human beings. Allah almighty denied the Jews who claimed that the Bait alMaqdis is their Qibla and is more important than the Ka'ba, insisting that the first house built for the place of worship is Bakka, the blessed place, which has many and steadfast worldly and enduring virtues that can be achieved through its presence and became a guide for mankind including for the Children of Israel, even people before and after their time.

The word Bakka has at least two meanings. The first is the place where the thawaf is performed, where Ka'ba is located, this word is taken from the Arabic root meaning crowd, this meaning is in accordance with the state of Mecca, especially in the Haj season. There is also the understanding of language Kaldani Bakka, the language used by prophet Ibrahim, which means city. In addition that the word Bakka, means the first worship house, it also mubarakan, meaning steady, constant and does not move. Mecca and Bakkah continually produce virtue, worldly and Hereafter, but there are some scholars who limit its understanding to a worldly or material and understand hudan lil 'Alamin by ukhrawi virtue meaning immaterial. (Shihab, 2007, p.157-159)

The Masjid al-Haram is the first mosque built on this earth according to the hadith narration of Imam Muslim, from Abu Dhar he said: "I asked Allah's Messenger (may peace be upon him) about the first mosque built on this earth, he replied:" Is Masjid al-Haram, "I said: then afterwards? He replied: "The mosque of al-Aqsa," I asked: "how long the time difference," he replied: "forty years, then (Allah made) all the place on earth as a mosque, so if you know the time of prayer, please do it" (Muslim, 1782, Ibn Asyur, Tafsir al-Tahrir wa al-Tanwir, p. 161-162, Ibn Katsir, Tafsir al-Qur'an al-'Azhim, p. 384). In addition, to Mecca and masjid al-haram, another example of place of a blessed place is Mount Sinai (al-Qashas 28: 30) and Masjid al-Aqsha (al-Isra' 17: 1), where a holy converse between prophet Musa and Allah took place. It is also explained that al-Buq'a al-Mubaraka relates to al-buq'ah where the Prophet Moses received the call of God. The word al-ayman can be interpreted right and can also be understood in terms of the superlative form of the word al-yumn, namely blessing. With this understanding, it is similar to the words muqaddas / sacred as mentioned in Taha 20: 12 and al-Nazi'at 79: 16. The above verse using the word of Allah and the word rabb. The use of the word Allah aims to designate God the Almighty, this is the main lafadz which is the special name as $\mathrm{He}$ is the obligatory of His being. As for the 
mention of the word rabb implies maintenance of guidance and education aimed at reassuring Moses that he was under His care and guidance (Shihab, 2007, p. 340-341).

Masjid al-Aqsa is blessed for being a place where many prophets were oridinally born there, and also for its fertile soil, and especially as the place of the isra' of Prophet Muhammad. Ibnu Katsir explains that the word hawlahu include temporal blessings, and ereafter as the fulfillment of their daily needs, many crops and fruits. While Qurthubi adds that the blessing here because of the many rivers that flow so many fertile trees and also because of the blessing of the prophets and pious people who are buried around the mosque, while al-Alusi said that the blessing of the Aqsa Mosque because it is a place of worship of the Prophets (Shihab, 2007, p.157-159, Qurthubi, Jami 'li Ahkam al-Qur'an vol. 15, p. 18, and al-Alusi, Ruh al-Ma'ani, vol. 15, p. 11).

Some mufassir explain that Syria whose eastern and western parts have been blessed with the fertility of the land, the number of trees and also the water and ease the sustenance for the people. Al-Alusi claims that the blessing of the place is due to the abode of the prophets and the righteous (al-Alusi, Ruh al-Ma'ani, vol. 9, pp 37-38, al-Suyuti, 1995, p. 253, al-Baghawi, 1996, p. 54). Syria is the site of the Prophet Abraham and the Prophet Lut (al-Anbiya '21: 71-72) rescued from Namrudz, the land of Kaldan in Iraq to hemisphere of Palestine (Syria-Palestine) famous with its fertile soil and cool air (Shihab, 2007, 479-480). Their safety in the appointed area refer to the blessings as the origin and place of the most of the prophets sent to disperse the Sharia of Allah on earth as the source of worldly goodness, ukhrawi, rahma lil 'alamin (Al-Tabari, Jami 'al-Bayan' an Ta'wil verse of the Qur'an, vol. 6, p, 77, al-Alusi, vol. 17, p. 70).

In the land of Syria there is Mount Thur, where Prophet Moses received the revelation (al-Qasas 28:30). Indeed, in that verse it is not called exactly the place but is mentioned in another verse (Maryam 19:52). According to al-Baghawi, Allah made the place a blessing because it was in that place that Prophet Moses was called by Allah and had a direct dialogue and was appointed as Prophet (al-Baghawi, p. 444) even God ever swore by calling Thur in the surah al-Tin. It shows that the place is undoubtedly has its glory and blessing as a place visited by many as a historic place.

Saba' inhabitants also get a blessing from God, as described in the Qur'an Surah Saba '(34:18): This verse describes some of the pleasure that God gave to the people of Saba barakah in the form of a blessed place, according to the mufassir, the place in question is a country of Syria and some are of the opinion that such place is the Bait al-Maqdis, or it can be interpreted that the blessing that stretches from Yemen to Syria (including Bait al-Maqdis means that they are given the pleasure of a convenience in the course of their country to the land of Syria with full of blessings with adjacent city, and secure the way so that the mufassir can walk safely on the time of day and night without being forced to stop in the desert and without trouble (Ibn Katsir, p. 534, al-Su'ud, p. 129, Qurthubi, p. 289, and alAlusi, p.130).

Thus, we can see clearly that God as the source of blessing (Hud, 11: 48, 73. S. Maryam 19: 31; S. al-Nur 24:61, and Ali Imran 3: 26); all places, goods, time, people, food and others are blessed by God, so that when human beings have the benefit of one or all of the blessings of creation, he will be happy in this world and in the Hereafter.

It is evident that any blessings come from Allah, and therefore all kinds of reciting the prayer to get the blessings always leaning towards Allah. It has been clear that God has priority and select a portion of His creature, He also has priority and gave a blessing in some places above most other places such as: Mecca, Medina and Al Aqsa Mosque. Similarly, Allah has put above most of the time from others such as: rain water and olives, al-Quran, etc. As already explained that Allah is Almighty Giver of abundant blessings, and specifically characterize himself with nature tabarak (giver of abundant blessings), and can 
be found word tabaraka repeated nine times in the Qur'an (Al-Araf 54, al-Mu'minun 14, alFurqan 1, 10, 61, Ghafir 64, al-Zukhruf 85, al-Rahman 78, and al-Muluk 1).

Divine blessings come from a direction that is often unexpected or perceived materially and can not be limited or measured. Therefore all additions that are not measured by human senses are named blessings (Shihab, 2007, p. 179-180). There is a blessing on something means a virtue that accompanies it, for example, a blessing in time, if that happens then the many virtues of activities to do that are usually not as much a virtue that can be done at this time. Blessings on food are relatively not much food available, but enough to feed the crowds that are usually not enough for that many people in ordinary situation.

From these two examples it appears that blessings vary according to the function of the blessed thing. The blessing of food for example is in the function of filling, giving birth to health diseases, encourage positive activities and others. This can be achieved not automatically, but because of the abundance of God's gifts. The gift in question does not undo the role of the laws of cause and effect which Allah has decreed, but by granting to whom it will be granted the ability to use and make use of such laws as efficiently and maximally as possible so that such blessings may be present, Quraish Shihab citing Thaba'tabai ((Shihab, 2007, p. 193-4).

\section{Conclusion}

The baraka is a gift from God who bestowed it upon objects, places and person, a material or spiritual benefit resulting from the will of God. In this sense, blessing is the beauty of a great and holy power, abundant power of supernatural and bestow a new quality to the objects that receive the blessings.

All kinds of pleasures and gifts that are part of kindness are sourced from God (AlNahl 16:53). Tabaraka Almighty granted to His creatures and has given to them, these blessings can not be counted and innumerable, so with continuity and permanence as well as increasing goodness and pleasure to humans is the blessings of Allah. In other words, it can be explained that the blessings belong to God and come from Him, He is the Giver of blessings.

\section{References}

Afifah, E. N. (2015). Korelasi konsep syukur dalam budaya Jawa dan ajaran Islam (studi kasus sedekah bumi di Desa Tegalharjo Kecamatan Trangkil Kabupaten Pati) (Doctoral dissertation, UIN Walisongo).

Al-Alusi, Mahmud ibn Fadhl, Ruh al-Ma'ani fi Tafsi al-Qur'an al-'Azhimwa Sab 'al-Matsani (Beirut: Dar Ihya'al-Turath al-'Arabi, n.d.).

Al-Baghawi, Abu Muhammad al-Husain ibn Mas'ud al-Farra, Tafsir al-Baghawi (Beirut: Dar al-Fikr, 1996), vol. 3.

Al-Baghawi, Abu Muhammad al-Husain ibn Mas'ud al-Farra, Tafsir al-Baghawi called Milestones al-Tanzil (Beirut: Dar al-Ma'rifah, $1406 \mathrm{H}$ ), cet 1, vol, 3.

Eliade, Mircea, The Sacred and The Profane, (New York: 1959).

Fatah, A. (2017). Keberkahan Al-Aqsha Perspektif Hermeneutika Schleiermacher. Jurnal Penelitian, 14(1), 1-22.

Al-Firuzabadi Majd al-Din Muhammad ibn Ya'qub, Bashair dzawi al-Tamyiz Latha'if fi alKitab al-'Aziz, (Beirut: Maktabah 'Ilmiyah, n.d.)

Ibn Asyur, Tafsir al-Tahrir wa al-Tanwir, vol. 3.

Ibn Katsir, Tafsir al-Qur'an al-'Azhim (Maktabah Syamilah, n.d.)

Al-Isfahani, al-Raghib, Mufradat Alfazh al-Qur'an (Jeddah: Dar al-Bashir, 1997) 
Al-Jawzi, Abu al-Faraj 'Abdurrahman ibn' Ali ibn Muhammad Zad al-Masir fi 'Ilm al-Tafsir, al-Maktabah al-Islami, $1404 \mathrm{H}$, cet to 3, vol. 9 .

Al-Jawzi, Ibn al-Qayyim, Jala' al-Afham fi al-Salah al-Salam wa' ala Khayr al-Anam, Yusuf Taha Tahqiq Syahin n.d.

Mulawarman, A. D. (2009). Menggagas Laporan Keuangan Syari'ah Berbasis Trilogi Ma'isyah-Rizq Maal. Tazkia Islamic Finance and Business Review, 4(1).

Mulawarman, A. D. (2009). Eksistensi Laporan Nilai Tambah Syari'ah Berbasis Rezeki. Jurnal Riset Akuntansi Indonesia,12(2), 103-120.

Muslim, Sahih Muslim, Kitab al-Masajid wa Madli 'al-Salah, vol. 4 no. 1782.

Pasmadi, A. K. (2009). Konsep Rezeki Dalam Pandangan Para Pedagang Pasar (Studi Kasus Para Pedagang Pasar Kleco Surakarta 2009) (Doctoral dissertation, Universitas Muhammadiyah Surakarta).

Al-Qaththan, Manna', Mabahits fi' Ulum al-Qur'an (Beirut: al-Risalah Mu'assasah, 1995).

Al-Qur'an Karim

Al-Qurtubi, Abu 'Abd Allah, Al-Jami 'li Ahkam Al-Qur'an (Cairo: Dar al-Sya'b, 1372)

Al-Razi, Fakhr al-Din, Tafsir al-Razi, vol. 13.

Ries, Julien, "Blessing." Translations of from French by Jeffrey C. Haight and Annie S. Mahler, in TheEncyclopedia of Religion Vol 2. Mircea Eliade ed. (New York: Mcmillan Publishing Company, 1987)

Shihab, M. Quraish Tafsir al-Mishbah, (Jakarta: Lentera Hati, 2007)

Siswandi, Konsep Yusuf Al-Qaradhawi Tentang Norma Dan Etika Konsumsi Menurut Pandangan Ekonomi Islam. (Bachelor Thesis, UIN Sultan Syarif Kasim)

Al-Su'ud, Muhammad ibn Muhammad al-'Imadi Abu, Irshad al-'aql Mazaya ila al-Salim alQur'an al-Karim (Beirut: Dar Ihya al-Turath al-'Arabi, tt), vol , 7.

Al-Suyuti, 'Abd Al-Rahman ibn al-Kanal al-Din, al-Durr al-Mantsur (Beirut: Dar al-Fikr 1995), vol. 3.

Al-Syanqiti, Muhammad ibn Muhammad al-Amin al-Mukhtaral-Jakanni, Adlwa 'al-Bayan $f i$ al-Qur'an Idlah bi al-Qur'an (Beirut: Dar al-Kutb al-'Ilmiyyah, 2003), printed 2, vol. 4.

Al-Tabari, Jami 'al-Bayan' an Ta'wil verse of the Qur'an (n.d.), vol. 6. 